\title{
FIGURATIVE LANGUAGE ANALYSIS IN CELINE DION'S SONG LYRICS FALLING INTO YOU ALBUM
}

\author{
Stella Vania Ardhyanti ${ }^{1}$, Supriyatiningsih ${ }^{2}$ \\ ${ }^{1}$ IKIP Siliwangi \\ ${ }^{2}$ IKIP Siliwangi \\ ${ }^{1}$ stellavania84@gmail.com, ${ }^{2}$ adesn28@gmail.com
}

\begin{abstract}
Figurative language is the ways to show the writer's thought use the special word, which have hidden meaning of it. This research analyzed Celine Dion's songs, they are Fly and Falling into You. The objectives of this research are to find out the types of figurative language and meanings of the figurative language in Celine Dion's songs. The writers take two songs from this album, they are Fly and Falling into You. The method of this research was qualitative descriptive. The data were taken from Genius.com website. Figurative language that the writers found in this research were six metaphors, two symbolisms, two imageries, two similes and one personification. In the Fly song there were four metaphors, and one symbolism. Besides in the Falling into You song there were two metaphors, one symbolism, two imageries, two similes, and one personification. The writers found the hidden meaning of these two songs. The Fly song told about parents who express deep sadness at the loss of her child. While, the Falling into You song told about someone who show his/her felling to someone they loved.
\end{abstract}

Keywords: Figurative Language, Song Lyrics, Contextual Meaning

\section{INTRODUCTION}

Language is important tools of people to communicate with another people. It is supported by Parmawati (2018) who states that language has central role on intellectual development, social, and emotional students to supported success student and learn all of lessons. Moreover, Sapir (2010, p. 8) defines language as "communication ideas, emotions, and desires" by arguing that language use convey varied and complex kinds of information group affiliations and relationship with his listener. It means, language has a meaning according to what the speaker wants to tell about. Thus, language is used to present idea, suggestion, or comment in the written or spoken form.

Language can be delivered in various ways such as, poetry, photograph, drama, dance and songs. Songs are a part of the literature that use music in addition. The same as poetry, the words are used in songs are words that have many meanings. The words in the song are called lyrics. This is in line with $\operatorname{Abrams}(2012$, p. 201) who states that lyric is any fairly short poem, emitted by a single speaker, who conveys a state of mind or a process of perception, thought, and feeling.

In lyric's writing, the songwriter or composer usually uses a figurative language to make their song more beautiful and fuller of meaning. It is related with Cuddon (2013) that mentions figurative language as a language which uses figures of speech; for example, metaphor, simile, and alliteration. Besides, Abrams (Norton et al., 2012) gives keywords to get understanding on figurative language that is apprehending the standard meaning of words in order to achieve 
some special meaning or effect. So, figurative language is a symbolic that avoids telling something directly to make certain effect.

Many experts who state their theories about figurative language, and the writers discuss about some theories from some experts. McMahan in Rahayu \& Fauzi (2016, p. 3) state that figurative language be distinguished into four types, they are: metaphor, simile, personification, allusion. In other hand, Kennedy (2007, p. 481) said that there are four types of figurative language, they are comparative figurative language, contradictive figurative language, repetitive figurative language, and correlative figurative language.

Song is a poem that uses music in its improvement. Prasetia, Masulan, \& Hamsia (2014) state that song to be more artistic when use the figurative language. The composer uses it in lyrics of song because it can make the listeners understands easier, interest, and give entertainment. Jamalus in (Setiawati \& Maryani, 2018) said that song can be explain as art works in singing to musical instruments accomplishment.

Lyric is a component in song. Pettijohn \& Sacco (2009) describe that lyric tell stories and communicate with listeners in a manner similar to how people have conversations with each other. Based on the explanation above, it can be concluded song is a poem that uses music and uses the figurative language in its lyrics, and lyrics is a component on song which like a stories or conversation between people.

Meaning is a description of someone's thought which given to the other in the form of language. It is related with Grice in Dale (1996, p. 2) who state that the meaning describes in terms of propositional attitude and act nations the conditions necessary and sufficient for a sentence to mean some specific thing among the members of a population. The writers focus on the contextual meaning of this research. According to Ullman in Rahayu \& Fauzi (Rahayu \& Fauzi, 2016), contextual meaning can be defined as a meaning of words that are found in particular situation. Trisnantasari $(2017$, p. 7$)$ concluded that contextual meaning is the terms explained the actual meaning according to the situation they were used. Thus, contextual meaning is the meaning that can be explained into several meanings, depending on the context.

According to the description above, the writers were exploring the figurative language found in the song lyric and the meaning of it. This topic is interesting to be discussed because it can make us better understand the meaning of lyrics in a song. The data were being taken from Celine Dion's album entitled Falling into You on 1996, and the writers analyzed two songs; they are Fly and Falling into You.

Céline Marie Claudette Dion or famous by name Céline Dion is French-Canadian singer. She was born on March 30, 1968. She conquered the pop chart in the 1990s with No.1 hits like The Power of Love and Because You Loved Me. Early in infancy, she sang with her siblings in a small club own up by her parents. From these early practices, Céline obtained the know-how to perform live. At the age of 12, Dion composed a song in her native French and sent it to a record company, where it gotten the attention of René Angélil, a respected manager. Angélil trusted in Céline so much that he actually pawned his house in order to finance her debut album. Already very well-liked and successful internationally, Céline outburst onto the U.S. stage when she makes a recording for the theme song to Disney's hit Beauty and the Beast (1991). The song got a Grammy and an Oscar, and from this point Céline has brought forth hit after hit. Her 'Falling into You' album, published in 1996, been the best-selling album of that year, was selling more than 25 million copies worldwide. In 1999, Dion took a hiatus in order to begin a 
family. She came back to the spotlight in 2002, was releasing yet another hit album. Starting in 2003, Céline began a three-year commitment to perform in an arena built for her in Las Vegas.

Hence, this study focused on figurative language commonly used in song lyric and the meaning contained in song lyrics. Based on the background above, the writers are interested in analyzing the figurative language and the meaning contained in it. This research would like to find out the types of figurative language and meanings of the figurative language in Celine Dion's songs entitled Fly and Falling into You.

\section{METHOD}

The writers applied qualitative method in this research. According to Sugiyono (2013), qualitative method was a research method which based on the philosophy of post positivism used to inspect the condition of natural objects, and the result of qualitative method focus on meaning. This research uses descriptive qualitative method. According to Nurmalasari and Apsari (2019), qualitative descriptive studies are the least encumbered studies, compared to other qualitative approaches, by a pre-existing theoritical or philosophical commitment. It means this research just gives the description about the content of this research and it do not calculate the data of this research.

The data were taken from Genius.com. According to Creswell (2012: 236) cited in (Aryana \& Apsari, 2018) "Analyzing qualitative data requires understanding how to make sense of text and image, so that you can form answers to your research questions". Then, the data were analyzed based on figurative language theory from Kennedy (Kennedy et al., 2007). After that, the writers identified the data and classified the figurative language of Fly and Falling into You song. Next, the writers find the hidden meaning of it. Last, made the report or conclusion based on the data that have got.

Some researchers have conducted some studies related to analysis song lyrics. They are as follow: the journal entitled "The Analysis of Figurative Language in Adele's Song Lyric" by Retnayhanti (2012). She found about eight kinds of figurative language, in four songs of Adele. She discovered the meaning of it with used contextual meaning. The writers look at the journal entitled "An Analysis of Figurative Language in Taylor Swift's Song Lyric" by Setiawati, Wilya and Maryani (Setiawati \& Maryani, 2018). They explored two songs of Taylor Swift, and found about five kinds of figurative language. Then, they found the hidden meaning on it, so that there will be no misunderstanding in interpreting the meaning.

Accordingly, the writers would analyze the figurative language from two song of Celine Dion. We will analyze Fly and Falling into You, from album Falling into You which was released on 1996. Afterward, we will find the hidden meaning of it.

\section{RESULTS AND DISCUSSION}

\section{Results}

Fly song by Celine Dion consist of 28 lines. The song contains heartbreaking meanings. The song is featured in Dion's Falling into Your album, which written by Jean-Jacques Goldman and Phil Galdston. The song encourages a child to fly to heaven. The lyrics see the sadness faced by parents for losing their children. The Falling into You song is one of the best-selling 
songs of Celine Dion in 1996. This song is from 28 lines, in 2 minutes and 59 seconds. The song means the feeling of someone who is in love.

Besides that, the writers also analyzed Falling into You song, which is a single with the same title as the album. This song is written by Billy Steinberg, Rick Nowels \& Marie Claire D'ubaldo, is made in 30 lines with a composition: 3 verses, 2 choruses, and outro, in 4 minutes and 19 seconds. This song tells the story of how beautiful it feels to be in love, and the song writers want the listeners to feel what they feel.

The writers collected figurative language of Celine Dion's songs into description based on those song. This way made readers known and ease to know the figurative language of Fly and Falling into You. Here was the figurative language of Celine Dion songs lyric:

Table 1 Figurative Language

\begin{tabular}{|c|c|c|}
\hline No. & Song's Title & Figurative Language \\
\hline 1. & Fly & $\begin{array}{l}\text { a. Metaphor } \\
\text { 1. Fly, fly little wing } \\
\text { 2. Fly where only angels sing } \\
\text { 3. Cross over to the other shore } \\
\text { 4. Your heart is pure, your soul is free } \\
\text { b. Symbolism } \\
\text { 1. Above the universe you'll climb }\end{array}$ \\
\hline 2. & Falling into You & $\begin{array}{l}\text { a. Imagery } \\
\text { 1. And I hear a voice say: "What's his is hers" } \\
\text { 2. And I can't even see the ground } \\
\text { b. Metaphor } \\
\text { 1. And in your eyes, I see ribbons of color } \\
\text { 2. I see us inside of each other } \\
\text { c. Personification } \\
\text { 1. I feel my unconscious merge with yours } \\
\text { d. Simile } \\
\text { 1. Falling like a leaf } \\
\text { 2. Falling like a star } \\
\text { e. Symbolism } \\
\text { 1. The walls begin to tumble down }\end{array}$ \\
\hline
\end{tabular}

\section{Discussion}

\section{Figurative Language and Contextual Meaning}

In those song, there are five kinds of figurative language such as metaphor, symbolism, imagery, personification, and simile.

a. Metaphor

In Fly and Falling into You lyric, there are some meaningful lyrics that are not a real sense or an indirect expression of the analogical comparison.

1. Fly Lyric

a) Fly, fly little wing

The lyrics encourage a child to fly to heaven.

b) Fly where only angels sing

In this sentence means that it is the place where the angel song is heaven. 
c) Cross over to the other shore

Other shore meanings are glance at this is another world. Crossing to other Worlds

d) Your heart is pure, your soul is free

Your heart is pure, your soul is free means the clean hearts and souls that children have.

Fly, fly little wing

The sentence above is included in metaphor, as in the Lyric's 'fly, fly little wing' means that the songwriters describe his willingness release 'little wing' his son goes. The second example appears in this lyric:

Fly where only angels sing

The second sentence, included in metaphor, because in the Lyric's 'fly where angels sing' indicates a sense of 'Angels Sing' show up the calling. Songwriters termed go when the angel has called. The third example appears in this lyric:

\section{Cross over to the other shore}

The third sentence in the example, be identified into metaphor, it can be seen in other words 'shore' which means that the word represents the songwriters as a place other than the world. The last example appears in this lyric:

\section{Your heart is pure, your soul is free}

In the example sentence is also included into metaphor, as can be seen in the words ' heart is pure ' that the writer intended to reveal hearts that do not have a sin and errors of any kind.

2. Falling into You Lyric

a) And in your eyes, I see ribbons of color

Ribbons of color mean attention to a single event or a visible feeling of eye highlight

b) I see us inside of each other

This lyric means that the author finds similarities in him so that it becomes a soul.

And in your eyes, I see ribbons of color

The phrase 'see ribbons of color' cannot be taken literally. Basically, we cannot see what's in someone's eyes. Yet, the phrase 'see ribbons of color' means the songwriters can see her happiness if she is with her lover. The other example of metaphor appears in this lyric:

\section{I see us inside of each other}

As well as the previous sentence, we cannot see what's in someone's eyes. So, this phrase shows that the songwriters and her lover do not see anyone else besides their lover. Because they were falling in love each other.

b. Symbolism

The meaning of symbolism is to compare something with another symbol (Cuddon, 2013). In both songs there are some lyrics that are included in the symbolism include:

1. Fly Lyric

a) Above the universe you will climb

Above the universe in this lyric was used to replace the word heaven. 
Above the universe you'll climb

This expression is identified by symbolism, because it has a meaning hidden behind that phrase. Above the words ' universe ' in this phrase indicates a higher place of human existence. So, this phrase means, he will go far to different world and will continue to dissipate further.

2. Falling into You lyric

a) The walls begin to tumble down

The walls in this lyric mean heart. So, the wall began to collapse means a heart that began to hurt.

The walls begin to tumble down

This phrase was identified by symbolism, because it has a hidden meaning behind the phrase. The word 'walls' in this phrase show her heart defense. So, this phrase means, the songwriter's heart defense was wrecked because of she falling in love with someone.

c. Imagery

In figurative language imagery only the falling into you song that contains that meaning. The sentence is in the word:

1. Falling into You Lyric

a) And I hear a voice say: "What's his is hers"

The word which show imagery is "hear". This lyric shows that the songwriters hears something and wants the listeners to listen to it.

b) And I cannot even see the ground

In this lyric, the word which show imagery is "see". In this case, the songwriters want to tell, about what they see. Through this lyric, listeners are invited to see things that are seen by songwriters, when they feel in love.

And I hear a voice say: "What's his is hers"

The lyric is identified as an imagery, because the phrase 'I hear a voice say' shows one sense 'hear'. The songwriters want to show what she heard, so that the listeners can feel it. The second example appears in this lyric:

\section{And I can't even see the ground}

This lyric is also identified as an imagery, because the phrase 'I cannot even see the ground' shows sense 'see'. Songwriters wants the listeners feel, that she can't see anyone else except her lover.

d. Personification

Personification means to refer to a dead object as a living object (Kreidler, 2013). As in falling into you song in a few lyrics containing the personification language style.

1. Falling into You Lyric

a) I feel my unconscious merge with yours

In this lyric there is the word "unconscious" and "merge with your". Of course, in this case it is obvious that the word unconscious belongs to the non-humanely, and the word joins me of course I am is humanely living. Then the sentence of it belongs to the personification.

I feel my unconscious merge with yours

From the sentence above, it is shown that unconscious is an abstract thing, which someone has. Sometimes this thing can't be felt by someone. However, the phrase 'my 
unconscious merge with yours' shows that the songwriters feels so in love with her lover.

e. Simile

Simile is compared things with other things by using a liaison word or a quote word (Cuddon, 2013).

1. Falling into You Lyric

a) Falling like a leaf, Falling like a star

The leaves and stars are as the word comparison or the word connective as the meaning of a sense of falling from the top of the tree as a leaf and falling from the sky as a star.

\section{Falling like a leaf}

Falling like a star

The word 'like' show this phrase is simile and that word compare the songwriter's situation with 'leaf' and 'star' were falling. These phrases show the songwriters situation who love someone no burden and without pressure, it just happens.

"Fly" is a heartbreaking tune featured on Dion's 1996 album Falling into You. Written by Jean Jacques Goldman and Phil Galdston, the song encourages a child to take flight to heaven. The lyrics look at the sadness a parent faces at the loss of a child: "Leave this lonely world of ours / Escape the sorrow and the pain / And fly again" but also finding peace, "Fly, fly little wing / Fly where only angels sing / Fly away, the time is right / Go now, find the light." From the lyrics we know it is clear, that the song lyrics are shown to express deep sadness at the loss of her child and they must be willing to let go and let them go to heaven.

The Falling into You song, literally means you falling into someone arms, but in this song, Falling into You means you falling in love with someone. This song tells the listeners to also feel how it feels to fall in love with someone. It is indicated by some lyrics, such as, it feels so good to falling into you (chorus1), catch me, don't let me drop, love me, don't ever stop (verse 3 ). Some lyrics above show that the songwriters want to show how beautiful it is to fall in love.

Based on the data, it can be concluded that there were four metaphors and one symbolism in Fly song, and two imageries, two metaphors, one personification, two similes and one symbolism in Falling into You song. It is related to theory Prasetia, Masulan, \& Hamsia (2014), who state that to be more artistic when use the figurative language and, in each lyric, have a meaning.

\section{CONCLUSION}

This research analyzed the two songs from famous singer Celine Dion, both tracks are taken from one of Celine Dion's album, which released on 1996. In the results of the discussion and the data obtained, the writers found some sort of meaning contained in the song. figurative language found in the track include imagery, symbolism, personification, simile, and metaphor. In the song entitled Fly, the writers found two figurative languages, there are metaphor and symbolism. Although, in the song entitled Falling into You, the writers found four figurative languages, there are metaphor, imagery, simile, symbolism, and personification. The writers used contextual meaning, to know and understand the meaning hidden in the song, so that there will not be misunderstandings in making sense of the song. Through the study, the writers hope 
this research can help people who are interested in analyzing literature. In addition, this data can also be used as a reference or example for future writers who want to further explore figurative language in a song text and open up a wider view and make readers think critically about analyzing text.

\section{ACKNOWLEDGMENTS}

The writers say the gratitude and thanks to God for blessings, health, opportunity, and smooth for us, so that we can complete this journal. This journal entitled "Figurative Language Analysis in Celine Dion's song Lyrics Falling into You Album" is submitted as final requirements at English Education Study Programming Language Faculty IKIP SILIWANGI Bandung.

The writers would like to thank everybody who was important to the successful realization of this final project. This journal is expected that it will be useful not only for the writers, but also for the readers. For this reason, constructive thoughtful suggestion and critics are welcomed.

\section{REFERENCES}

Aryana, S., \& Apsari, Y. (2018). Analysing Teacher's Difficulties In Teaching Listening. ELTIN JOURNAL, Journal of English Language Teaching in Indonesia, 6(2), 100-106.

Bloomfield, L., \& Sapir, E. (2010). Language: An Introduction to the Study of Speech. In The Classical Weekly (Vol. 15). https://doi.org/10.2307/4388302

Cuddon, J. (2013). A dictionary of literary terms and literary theory (5th ed., Vol. 29). https://doi.org/10.5860/choice.29-1847

Dale, R. E. (1996). The Theory of Meaning. New York: New York University.

Editors, B. (2014, April 2). Celine Dion Biography. Retrieved March 26, 2019, from The Biography.com website: https://www.biography.com/people/celine-dion-9542132

Genius Media Group Inc. (n.d.). Falling Into You Lyrics. Retrieved March 20, 2019, from Genius.com: https://genius.com/Celine-dion-falling-into-you-lyrics

Genius Media Group Inc. (n.d.). Fly Lyrics. Retrieved March 24, 2019, from Genius.com: https://genius.com/Celine-dion-fly-lyrics

Kennedy, X. J., Davis, J., Broughton, P., Fenstermaker, J. J., \& Wood, M. (2007). LiteratureLiterature: An Introduction to Fiction, Poetry, and Drama. College Composition and Communication. https://doi.org/10.2307/356271

Kreidler, C. W. (2013). Introducing English semantics, second edition. https://doi.org/10.4324/9781315886428

Literary Devices. (n.d.). Figurative Language. Retrieved March 24, 2019, from Literary Devices : Definition and Example of Literary Terms: https://literarydevices.net/figurativelanguage/

Magwire, T. J. (n.d.). Celine Dion Biography. Retrieved March 26, 2019, from IMBd: https://www.imdb.com/name/nm0001144/bio

Norton, D. S., Rushton, P., \& Abrams, M. H. (2012). A Glossary of Literary Terms (Tenth). https://doi.org/10.2307/354930

Nurmalasari, M., \& Apsari, Y. (2019). Improving Students' Participation in Speaking English Using Snowball Throwing Technique. PROJECT (Professional Journal of English Education), 2(2), 14-20.

Parmawati, A. (2018). The Study Correlation Between Reading Habit And Pronunciation Ability At The Second Grade Students Of Ikip Siliwangi. Eltin Journal, Journal Of English Language Teaching In Indonesia, 6(1), 46-52. 
Pettijohn, T. F., \& Sacco, D. F. (2009). The Language of Lyrics. Journal of Language and Social Psychology, 28(3), 297-311. https://doi.org/10.1177/0261927x09335259

Prasetia, N. L., Masulah, \& Hamsia, W. (2014). Analysis Figure of Speech in Adele's Songs. Tell Journal, 2(1), 15-18.

Rahayu, P., \& Fauzi, A. R. (2016). Figurative Language in Westlife Second album Coast to Coast.

Retnayanthi, P. A. (2012). The Analysis of Figurative Languages in Adele's Song Lyrics.

Setiawati, W., \& Maryani. (2018). an Analysis of Figurative Language in Taylor Swift' S Song Lyrics. Professional Journal of English Education, 01(03), 261-268.

Sugiyono. (2013). Metode Penelitian Pendidikan Pendekatan Kuantitaif, Kualitatif, dan R\&D. Metode Penelitian Pendidikan Pendekatan Kuantitaif, Kualitatif, Dan $R \& D$. https://doi.org/10.1007/s13398-014-0173-7.2

Trisnantasari, I. (2017). A Semantic Analysis on Ed Sheeran Songs. 1-9. 